\title{
Influence of FTO rs9939609 and Mediterranean diet on body composition and weight loss: a randomized clinical trial
} (2) CrossMark

\author{
Laura Di Renzo ${ }^{1 \dagger}$, Giorgia Cioccoloni ${ }^{2^{*}+} @$, Simone Falco ${ }^{1 \dagger}$, Ludovico Abenavoli ${ }^{3}$, Alessandra Moia ${ }^{4}$, \\ Paola Sinibaldi Salimei ${ }^{1}$ and Antonino De Lorenzo ${ }^{1}$
}

\begin{abstract}
Background: The Mediterranean diet (MeD) plays a key role in the prevention of obesity. Among the genes involved in obesity, the Fat mass and obesity-associated gene (FTO) is one of the most known, but its interaction with MeD remained uncertain so far.

Methods: We carried out a study on a sample of 188 Italian subjects, analyzing their FTO rs9939609 alleles, and the difference in body composition between the baseline and a 4-weeks nutritional intervention. The sample was divided into two groups: the control group of 49 subjects, and the MeD group of 139 subjects.

Results: We found significant relations between $\mathrm{MeD}$ and both variation of total body fat $(\triangle \mathrm{TBF}$ at) $(p=0.00)$ and gynoid body fat $(p=0.04)$. $\triangle$ TBFat $(\mathrm{kg})$ demonstrated to have a significant relation with the interaction diet-gene $(p=0.04)$, whereas FTO was associated with the variation of total body water $(p=0.02)$.
\end{abstract}

Conclusions: MeD demonstrated to be a good nutritional treatment to reduce the body fat mass, whereas data about FTO remain uncertain. Confirming or rejecting the hypothesis of FTO and its influence on body tissues during nutritional treatments is fundamental to decide whether its effect has to be taken into consideration during both development of dietetic plans and patients monitoring.

Trial Registration ClinicalTrials.gov Id: NCT01890070. Registered 01 July 2013, https://clinicaltrials.gov/ct2/show/NCT01 890070

Keywords: Nutrigenetics, FTO, Mediterranean diet, Body composition

\section{Background}

The Mediterranean diet $(\mathrm{MeD})$ is considered one of the healthiest dietetic pattern in the world [1]. It is characterized by a high consumption of olive oil, fish, fruits, legumes, vegetables, unrefined cereals, a moderate consumption of wine and dairy products, and a low consumption of non-fish meat products [2]. According to several studies, thanks to its peculiar distribution of macro and micronutrients, this dietary model plays a

\footnotetext{
*Correspondence: giorgia.cioccoloni@students.uniroma2.eu

'Laura Di Renzo, Giorgia Cioccoloni and Simone Falco contributed equally to this work

${ }^{2}$ PhD School of Applied Medical-Surgical Sciences, University of Rome

Tor Vergata, Via Montpellier 1, 00133 Rome, Italy

Full list of author information is available at the end of the article
}

key role in the prevention of a wide number of chronic diseases, such as cardiovascular diseases (CDVs), diabetes and metabolic syndrome [3-5], making an important contribution to the weight loss, especially if it is associated with energy restriction and constant physical activity [6]. In view of above, it is worth recalling that this dietary models can also prevent and treat obesity [7], a disease, usually classified through that provides alterations in body composition like abnormal or excessive fat accumulation [8-10]. This medical condition is caused by a several numbers of co-factors, such as psychological problems, sedentary life and incorrect dietetic habits $[11,12]$, and it is an important risk factor for all those aforementioned diseases fought by the Mediterranean diet [13]. Therefore, in this context, it is

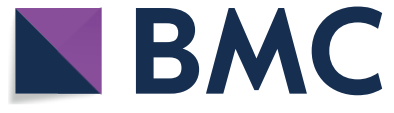

(c) The Author(s) 2018. This article is distributed under the terms of the Creative Commons Attribution 4.0 International License (http://creativecommons.org/licenses/by/4.0/), which permits unrestricted use, distribution, and reproduction in any medium, provided you give appropriate credit to the original author(s) and the source, provide a link to the Creative Commons license, and indicate if changes were made. The Creative Commons Public Domain Dedication waiver (http://creativecommons.org/ publicdomain/zero/1.0/) applies to the data made available in this article, unless otherwise stated. 
understandable why this dietary model plays a key role in the health protection.

Nevertheless, independently from the dietetic habits, also genetics play a key role in the development of obesity [14]. In the human genome, a several number of genes are involved in the obesity, and Fat mass and obesity-associated gene (FTO) is surely one of the most important. This gene, widely expressed in several fetal and adult tissues, is located on chromosome 16 (16q12.2), and encodes for the enzyme alpha-ketoglutarate-dependent dioxygenase [15]. This enzyme is implied in the regulation of both the control of adipocyte thermogenesis and differentiation, contributing considerably to the body fat accumulation [16]. Furthermore, it contributes to the regulation of energy homeostasis and metabolic rate [17], increasing also the food intake [18]. Finally, among the other activities, is implicated in the repairs of alkylated DNA and RNA via oxidative demethylation [19]. Among the several variants of this gene, FTO rs9939609 is one of the best-know. It is located in the first intron of the gene and, in 2007, it was for the first time associated with the body mass [20]. Subsequently, further studies demonstrated that the allele A of FTO rs9939609 is related to both a higher body mass index and body circumferences [21, 22], and, among different ethnicities, also Italian population demonstrated the same results [23]. Furthermore, this SNP is included among the genetic etiological factors in the development of both metabolic syndrome and Type-2 diabetes [24, 25], and allele A was also associated with a higher fat and lean mass $[26,27]$. In a PREDIMED substudy, it was observed that homozygous subjects for A allele had the highest baseline body weight, but also the lowest body weight gain after 3 years of Mediterranean-style intervention, compared to TT genotype. However, no interaction between nutritional intervention and the polymorphism was found $[28,29]$. On the other hand, OrtegaAzorín et al. [30] demonstrated consistent gene-diet interactions between FTO rs9939609 and Melanocortin-4 Receptor (MC4R) rs17782313 genes and to the Mediterranean diet adherence in the type 2 diabetes risk. The same effect was observed in obese phenotypes in Iranian population. Subjects with minor allele carriers of FTO variants rs9939973, rs8050136, rs1781749, and rs3751812 had a lower risk of obesity when they had a higher Mediterranean dietary score compared to wild-type homozygote genotype carriers [31].

In the light of these observations the objective of this study was to investigate about the possible influence of FTO rs9939609 variant on both weight loss and modification of body composition in Italian subjects, after having followed a 4-weeks dietetic intervention based on the
Mediterranean model, in order to see if this polymorphism could influence the response to a specific dietary treatment.

\section{Methods \\ Study design and subjects}

The study was carried out between January 2017 and March 2018 at the Section of Clinical Nutrition and Nutrigenomics, Department of Biomedicine and Prevention of the University of Rome Tor Vergata. The initial sample recruited was composed of 300 subjects, who came up for the first time for a nutritional-medical checkup at the Clinical Nutrition and Nutrigenomic Section at the University of Rome Tor Vergata. To be eligible, each individual had to belong to the Caucasian race, to be Italian and older than 16 years old. Furthermore, for each subject, the medical assessment was evaluated before and after the application of prescribed nutritional treatments. We have pooled the sample in two groups, 150 subjects followed, for a period of 4 weeks, a Mediterranean diet $(\mathrm{MeD})$, whereas the remaining 150 were allocated, within the same period, in the control group (CTR). The randomization and allocation of the study participants was performed using the IBM SPSS 21.0 for Windows (IBM Corp., Armonk, NY, USA). All the individuals included in the study approved their participation by learning and signing the informed consent, which was drawn up in accordance with the commissariat of the Ethics Committee of Medicine, University of Rome Tor Vergata and with the Helsinki Declaration of 1975 as revised in 1983. Trial Registration: this protocol has been registered by ClinicalTrials.gov, ID: NCT01890070.

\section{Anthropometric, bioimpendance analysis, and dual-energy X-ray absorptiometry}

After a 12-h overnight fasting, all subjects underwent anthropometric evaluation. All the individuals were instructed to take off their clothes and shoes before undergoing the measurements. Body weight was assessed with balance scale to the nearest $0.1 \mathrm{~kg}$ (Invernizzi, Rome, Italy). Height was evaluated using a stadiometer (Invernizzi, Rome, Italy) to the nearest $0.1 \mathrm{~cm}$. BMI was calculated using the formula BMI $=$ body weight $/$ height ${ }^{2}\left(\mathrm{~kg} / \mathrm{m}^{2}\right)$. Waist, hip, neck and abdomen circumferences were assessed using a flexible steel metric tape to the nearest $0.5 \mathrm{~cm}$, according to the International Society for the Advancement of Kin anthropometry protocol and National Institute of Health Guidelines [32].

Body composition analysis was performed using both dual-energy X-ray absorptiometry (DXA) (I-DXA, GE Medical Systems, Milwaukee, WI, USA) and bioelectrical impedance analysis (BIA 101S, Akern/RJL Systems, 
Pontassieve, Florence, Italy). DXA was carried out to evaluate total, android and gynoid, of fat mass percentage (FM\%), fat mass (FM) and lean mass (LM) in Kg. Total fat mass percentage (Total FM\%) was calculated as Total body fat mass (Total FM) divided by the total mass of all tissues (Total LM), including the total body bone (TBBone), as the following: Total FM\% = (Total FM/(Total FM + Total LM + TBBone $)) \times 100$ [33]. Bioelectrical impedance analysis was carried out to evaluate resistance $(\mathrm{R})$, reactance $(\mathrm{Xc})$, phase angle (PA), hydration, exchange $\mathrm{Na} / \mathrm{K}$, total body water (TBW), extracellular water (ECW), intracellular water (ICW), body cell mass (BCM), body cell mass index (BCMI). Finally, waist/hip ratio (WHR) was analyzed and evaluated according to the clinical risk thresholds, equivalent to WHR $>0.9$ for men and WHR $>0.85$ for women [34].

According to De Lorenzo et al. [10], we categorized our population based on phenotype classification through BMI and TBFat\% as follows: underweight (UW) $(\mathrm{BMI}<18.50)$; normal-weight (NW) $(18.50 \leq \mathrm{BMI}<25$ or BMI $\geq 25$ but Total TBFat\% lower than $30 \%$ for women and $25 \%$ for men); normal weight obese (NWO) $\quad(18.50 \leq \mathrm{BMI}<25$ and $\mathrm{TBFat} \%$ higher than $30 \%$ for women and $25 \%$ for men); Preobese (PreOb) $(25 \leq \mathrm{BMI}<30$ and $\mathrm{TBFat} \%$ higher than $30 \%$ for women and $25 \%$ for men); Obesity I $(30 \leq \mathrm{BMI}<35)$; Obesity II $(35 \leq \mathrm{BMI}<40)$; Obesity III $(\mathrm{BMI} \geq 40)$.

\section{DNA isolation and RTq-PCR analysis}

The phenol-chloroform extraction described by Barker et al. [35] was used to extract the Genomic DNA, which was collected, in turn, via saliva swab. To prepare the gDNA for the genotyping, a two allele-specific fluorescent probe including a PCR primer pair (TaqMan SNP Genotyping Assays, Life Technologies, CA, USA) and a master mix including dNTPs and Taq DNA Polymerase (TaqPath ProAmp Master mix Life Technologies, CA, USA) were used. The FTO rs9939609 context sequence was the following: GGTTCCTTGCGACTGCTGTGA ATTT [A/T] GTGATGCACTTGGATAGTCTCTGTT. Finally, SNP genotyping assessment was executed using a Real-Time PCR analysis (Applied Biosystems StepOnePLus Real-Time PCR, Life Technologies, CA, USA), according to the manufacturer's instructions.

\section{Dietary assessments}

At baseline subjects food intake was assessed with a 3-day diet records completed for 2 weekdays and 1 weekend day [36]. Participants were instructed to record weight and/or measures of foods and beverages consumed. Diet records were reviewed to clarify the amounts of foods ingested. The estimated intake of macronutrients was calculated by using Dietosystem dietary software (DS Medica S.r.l., Milan, Italy).

\section{Dietary intervention}

In MeD intervention, an isocaloric Mediterranean diet in which the daily macronutrients intake was distributed as follows: $55 \%$ of carbohydrates, $20 \%$ of protein $(>50 \%$ of vegetable derivation), $<25 \%$ of lipids (on total daily energy intake: saturated fat $<10 \%, 6-10 \%$ polyunsaturated fatty acids (PUFA), n-6/n-3 PUFA ratio of 3:1, 15\% of monounsaturated fatty acids (MUFA); $<1 \%$ trans-fatty acids) and $25 \mathrm{~g}$ of fiber.

For each subject, the energy intake was calculate according to the estimation of the rest energy expenditure (REE), which was determined using the Weir Formula:

$$
\operatorname{REE}=\left[\left(3.94 \times \mathrm{VO}^{2}\right)+\left(1.106 \times \mathrm{VCO}^{2}\right)\right] \times 1.44
$$

[37], in which $\mathrm{VO}^{2}$ and $\mathrm{VCO}^{2}$ were calculated as follows: $\mathrm{VO}^{2}=$ Total LM DXA $(\mathrm{kg}) \times 5$ for females, $\mathrm{VO}^{2}=$ Total LM DXA $(\mathrm{kg}) \times 4.5$ for males and $\mathrm{VCO}^{2}=\mathrm{VO}^{2} \times 0.85$ [38].

The REE was multiplied for the proper physical activity level (PAL) according to the WHO and Food and Agriculture Organization of the United Nations (FAO) recommendations [39].Conversely, in the control group, the subjects did not follow any specific diet, but they have received general recommendations on healthy nutritional habit and were only monitored, even though also for these subjects REE and the energy intake were evaluated as aforementioned.

\section{Analysis of blood sample}

Blood samples, taken after a 12-h overnight fast, were collected in sterile tubes containing EDTA (Vacutainer ${ }^{\circledR}$ ) and put on ice. Plasma, after being separated by centrifugation (1600 rpm, at $4{ }^{\circ} \mathrm{C}$ for $\left.10 \mathrm{~min}\right)$, was removed, aliquoted and stored at $-80{ }^{\circ} \mathrm{C}$. All clinical chemistry analyses, except serum lipid plasma and glucose analysis, were performed using an ADVIA $^{\circledR} 1800$ Chemistry System (Siemens Healthcare), following standard procedures [40]. Plasma glucose concentrations were measured through the glucose oxidase method and automated glucose analyzer (COBAS INTEGRA 400, Roche Diagnostics, Indianapolis, IN, USA); serum lipid profile constituents were evaluated by standard enzymatic colorimetric techniques (Roche143 Modular P800, Roche Diagnostics, Indianapolis, IN, USA).

\section{Statistical analysis}

The SNP-HWE program was used to calculate the HardyWeinberg equilibrium (HWE) for FTO rs9939609, and 
the result was tested using the $x^{2}$ analysis [41]. To analyze the sample, the subjects were divided into carrier/noncarrier (carrier for A allele vs homozygous $\mathrm{T}$ ) and into $\mathrm{MeD}$ and CTR (Mediterranean diet vs Control group). The Kolmogorov-Smirnov test was used to analyze the distribution of variables, and data were normalized according to Z-score transformation. T-test analysis was performed between A carriers and TT genotype at baseline, as well as ANOVA one way analysis, adjusted with Bonferroni post hoc analysis, between the genotype/ treatment groups in order to see significant differences among groups $(\mathrm{p}<0.05)$. Change $(\Delta)$ in body weight $(\mathrm{kg}), \mathrm{BMI}$, neck, waist, abdomen and hip circumferences (cm), WHR, R, Xc, BCM (kg), Na/K, TBW (L), ECW (L), $\mathrm{ICWb}(\mathrm{L}), \mathrm{BCMI}$, Android Bfat (\%), Gynoid Bfat (\%), TBFat (\%), Android Bfat (Kg), Gynoid Bfat (Kg), TBFat $(\mathrm{Kg})$, Android BLean $(\mathrm{kg})$, Gynoid BLean $(\mathrm{kg})$, TBLean $(\mathrm{kg})$ and REE were calculated by subtracting measurements recorded before the beginning of the nutritional treatments, from the measurement recorded after the completion of the nutritional intervention. In order to compare the differences in mean of the aforementioned values, respectively for A carriers and TT genotype, gene, diet and gene-diet interaction analyses were carried out using a Generalized Linear Model (linear GLM), adjusted for sex and age. TBFat $(\mathrm{kg})$ was selected as a parameter to calculate minimum sample size. The minimum sample size was calculated using a two-tailed one-sample Student's t-test, considering:(i) TBFat to be detected between baseline and $M E D|\delta|=-3.86 \mathrm{~kg}$; (ii) SD of the paired differences $S D=6.38 \mathrm{~kg}$, (iii) type I error probability $\alpha=0.05$ and power $1-\beta=0.95$. The result was a minimum sample size of 36 for MED and 12 for CTR group. Significance was set as $\mathrm{p}<0.05$ and the statistical analysis was performed using IBM SPSS 21.0 for Windows (IBM Corp., Armonk, NY, USA).

\section{Results}

\section{Population characteristics}

The enrolled 300 subjects met the inclusion criteria and nobody declined to participate. Subjects were equally randomized allocated in MeD group and CTR group. During this clinical trial, 11 subjects from MeD group and 101 subjects from CTR group abandoned the study as specified in Fig. 1. In fact, 5 subjects form the MeD group abandoned the study for poor weight loss results and 6 subjects for poor adherence to the diet therapy. On the other hand, in the CTR group 101 subjects abandoned the study since they did not see any kind of health benefits or improvement. The final sample analyzed consisted of 188 patients, divided as follow: 139 subjects in $\mathrm{MeD}$ group and 49 for CTR group. These patients successfully participated and completed the study protocol.
In our sample, the HWE was respected $(p>0.05)$. The comprehensive description of the whole sample population at baseline can be seen in Table 1. All results were stated as mean and standard deviation. The average age of the individuals was $46.83 \pm 15.01$ years, $62.2 \%$ females and $37.8 \%$ males (Table 1). According to the statistical analysis, at baseline, carriers and no carriers differs significantly only for age, diastolic blood pressure, R, basophils count and unsaturated fatty acids and polyunsaturated fatty acids intake $(\mathrm{p}<0.05)($ Table 1$)$. Genotype frequencies of our individuals (TT: 0.310; AA: 0.190; AT: $0.500)$ are similar to the ones shown in TSI population (TT: 0.327, AA: 0.252, AT: 0.421), and the same result was demonstrated about the allele frequencies, similar between TSI (T: 0.537; A: 0.463) and our sample (T: 0.550; A: 0.450) (Table 2). The average BMI of the subject was $29.39 \pm 6.99$, and the average Total FM $(\mathrm{kg})$ was $37.3 \pm 9.76$. Finally, in order to have a detailed description of the sample, in Table 3 the individuals, at the baseline, were divided by genotype and categorized according to phenotype classification.

At baseline, differences were highlighted between TT genotype and A carriers for age, DBP, BCM ( $\mathrm{kg})$, basophils $(1000 / \mu \mathrm{L})$, unsaturated fatty acids $(\mathrm{g})$ and polyunsaturated fatty acids $(\mathrm{g})$ intake $(\mathrm{p}<0.05)$.

Among the genotype/treatment groups significances were found for SBP between control group TT genotype and Med group TT genotype, DBP between control group TT genotype and the other groups (control group A carriers, Med group TT genotype and Med group A carriers) and neck circumference between control group TT genotype and Med group A carriers, control group A carriers and Med group TT genotype and Med group A carriers $(\mathrm{p}<0.05)$. No other statistical significance were found at baseline between groups.

\section{Influences of FTO rs9939609 and nutritional intervention on BMI, body composition and metabolism}

In this study, the GLM analysis was used to demonstrate the statistical significance between FTO rs9939609 carriers $\mathrm{A}$ and TT genotype together with the nutritional intervention.

According to the results, TBFat $(\mathrm{kg})$ decreases dependently both of the nutritional intervention $\left(\mathrm{p}_{\mathrm{D}}=0.00\right)$ and the interaction gene-diet $\left(\mathrm{p}_{\mathrm{GD}}=0.04\right)$, showing a significant difference between $\mathrm{MeD}$ and CTR, but also suggesting a potential role, even though not statistically significant, of FTO rs9939609 $\left(\mathrm{p}_{\mathrm{G}}=0.06\right)$, since A carrier CTR gained weight sensibly more than TT genotype $\mathrm{CTR}$, and A carrier MeD lost more weight than TT genotype $\mathrm{MeD}(\mathrm{MeD} / \mathrm{TT}$ genotype $=-3.59 \pm 4.78 ; \mathrm{MeD} / \mathrm{A}$ carriers $=-3.97 \pm 6.97 ; \mathrm{CTR} / \mathrm{TT}$ genotype $=1.93 \pm 5.54$; $\mathrm{CTR} / \mathrm{A}$ carriers $=6.11 \pm 9.60$ ) (Table 4). Furthermore, 


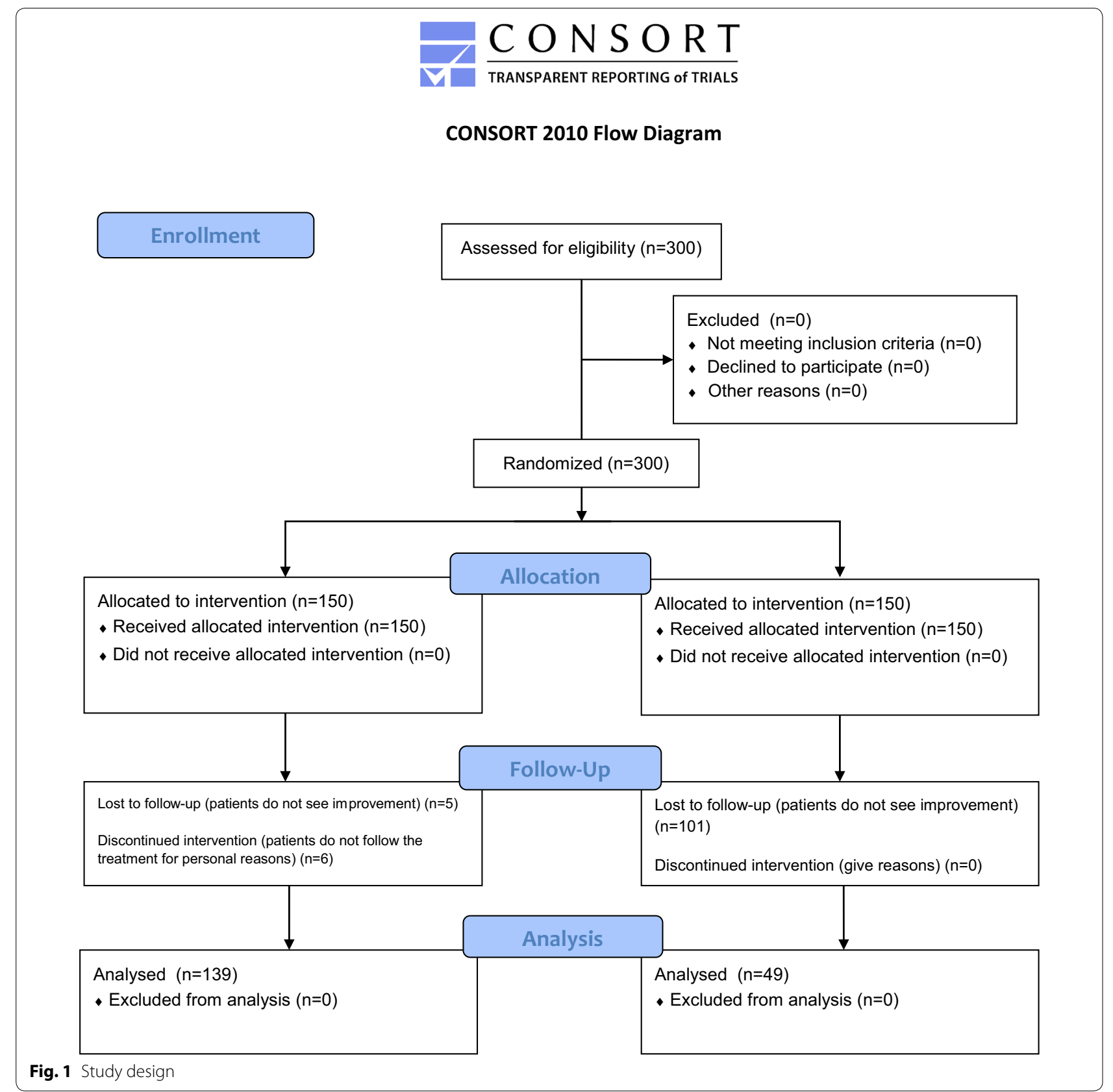

MeD group, regardless of FTO rs9939609 $\left(\mathrm{p}_{\mathrm{G}}=0.70\right.$; $\mathrm{p}_{\mathrm{GD}}=0.32$ ) (Table 4), lost a higher amount of Gynoid BFat (\%) compared to CTR $(\mathrm{p}=0.04)(\mathrm{MeD} / \mathrm{TT}$ genotype $=-2.94 \pm 5.14 ; \quad \mathrm{MeD} / \mathrm{A} \quad$ carriers $=-1.67 \pm 3.51$; $\mathrm{CTR} / \mathrm{TT} \quad$ genotype $=0.03 \pm 1.26 ; \quad \mathrm{CTR} / \mathrm{A} \quad$ carriers $=-0.42 \pm 1.74)$ (Table 4).

The bioelectrical impedance analysis highlighted that TBW, was significantly reduced in A carriers compared to TT genotype $\left(\mathrm{p}_{\mathrm{G}}=0.02\right)$, independently of nutritional intervention $\left(\mathrm{p}_{\mathrm{D}}=0.48 ; \mathrm{p}_{\mathrm{GD}}=0.47\right)$
$(\mathrm{MeD} / \mathrm{TT}$ genotype $=-0.83 \pm 1.63 ; \mathrm{MeD} / \mathrm{A}$ carriers $=-1.88 \pm 4.35 ; \quad \mathrm{CTR} / \mathrm{TT} \quad$ genotype $=0.70 \pm 3.04$; CTR/A carriers $=-1.75 \pm 3.28$ ) (Table 4). All the other results were not statistically significant $(p>0.05)$.

\section{Discussion}

Among the different dietetic patterns, the Mediterranean diet is surely one of the healthiest in the world [1]. In fact, several studies demonstrated its capability to prevent different cardiovascular and metabolic diseases, such as 
Table 1 Descriptive characteristics of study population

\begin{tabular}{|c|c|c|c|}
\hline & Total & TT genotype & A carriers \\
\hline Age (years) & $46.83( \pm 15.01)$ & $43.29( \pm 16.04)^{\mathrm{a}}$ & $48.36( \pm 14.34)^{\mathrm{a}}$ \\
\hline Systolic BP (mm Hg) & $126.14( \pm 17.03)$ & $127.96( \pm 20.80)$ & $125.42( \pm 15.41)$ \\
\hline Distolic BP (mm Hg) & $86.62( \pm 19.45)$ & $94.42( \pm 23.64)^{\mathrm{a}}$ & $83.30( \pm 16.48)^{a}$ \\
\hline Height (cm) & $165.85( \pm 9.04)$ & $166.17( \pm 9.52)$ & $165.71( \pm 8.86)$ \\
\hline Weight (kg) & $80.9( \pm 21.14)$ & $77.83( \pm 20.47)$ & $82.23( \pm 21.36)$ \\
\hline $\mathrm{BMI}\left(\mathrm{kg} / \mathrm{m}^{2}\right)$ & $29.39( \pm 6.99)$ & $28.09( \pm 6.68)$ & $29.95( \pm 7.08)$ \\
\hline Neck circumference (cm) & $39.47( \pm 4.34)$ & $38.71( \pm 3.80)$ & $39.70( \pm 4.48)$ \\
\hline Waist circumference (cm) & $90.95( \pm 16.38)$ & $87.63( \pm 16.45)$ & $92.23( \pm 16.25)$ \\
\hline Abdomen circumference (cm) & $103.31( \pm 15.75)$ & $98.71( \pm 14.81)$ & $104.70( \pm 15.85)$ \\
\hline Hip circumference (cm) & $106.49( \pm 12.09)$ & $103.38( \pm 9.84)$ & $107.68( \pm 12.68)$ \\
\hline WHR & $0.85( \pm 0.11)$ & $0.84( \pm 0.11)$ & $0.86( \pm 0.11)$ \\
\hline $\mathrm{R}$ & $505.78( \pm 96.34)$ & $538.67( \pm 83.75)^{\mathrm{a}}$ & $492.62( \pm 98.31)^{\mathrm{a}}$ \\
\hline$X_{c}$ & $55.56( \pm 13.15)$ & $57.14( \pm 10.34)$ & $54.93( \pm 14.13)$ \\
\hline PA & $6.42( \pm 1.33)$ & $6.24( \pm 1.11)$ & $6.49( \pm 1.41)$ \\
\hline $\mathrm{BCM}(\mathrm{kg})$ & $30.27( \pm 8.37)$ & $28.03( \pm 7.16)^{a}$ & $31.18( \pm 8.68)^{\mathrm{a}}$ \\
\hline $\mathrm{Na} / \mathrm{K}$ & $0.94( \pm 0.16)$ & $0.97( \pm 0.12)$ & $0.93( \pm 0.17)$ \\
\hline BCM (\%) & $55.75( \pm 6.97)$ & $54.46( \pm 4.92)$ & $56.30( \pm 7.66)$ \\
\hline TBW (L) & $40.36( \pm 9.52)$ & $38.44( \pm 8.60)$ & $41.14( \pm 9.81)$ \\
\hline $\mathrm{ECW}(\mathrm{L})$ & $17.76( \pm 4.46)$ & $17.23( \pm 3.94)$ & $17.97( \pm 4.66)$ \\
\hline ICW (L) & $22.76( \pm 6.45)$ & $21.43( \pm 5.62)$ & $23.33( \pm 6.73)$ \\
\hline BCMl & $12.5( \pm 6.58)$ & $11.68( \pm 5.64)$ & $12.83( \pm 6.92)$ \\
\hline Android FM\% & $43.19( \pm 12.54)$ & $42.18( \pm 11.70)$ & $43.55( \pm 12.87)$ \\
\hline Gynoid FM\% & $41.03( \pm 10.93)$ & $40.90( \pm 10.32)$ & $41.09( \pm 11.21)$ \\
\hline Total FM\% & $37.3( \pm 9.76)$ & $36.56( \pm 8.83)$ & $37.62( \pm 10.15)$ \\
\hline Android FM (kg) & $3.13( \pm 2.02)$ & $2.84( \pm 1.79)$ & $3.25( \pm 2.10)$ \\
\hline Gynoid FM (kg) & $5.45( \pm 2.3)$ & $5.15( \pm 2.03)$ & $5.57( \pm 2.39)$ \\
\hline Total FM (kg) & $29.93( \pm 14.88)$ & $28.48( \pm 13.80)$ & $30.56( \pm 15.33)$ \\
\hline Android LM (kg) & $3.25( \pm 0.88)$ & $3.31( \pm 0.95)$ & $3.23( \pm 0.85)$ \\
\hline Gynoid LM (kg) & $6.88( \pm 1.82)$ & $6.92( \pm 1.95)$ & $6.86( \pm 1.77)$ \\
\hline Total LM (kg) & $47.6( \pm 11.03)$ & $47.31( \pm 11.69)$ & $47.73( \pm 10.80)$ \\
\hline $\mathrm{VO}^{2}$ & $231.81( \pm 46.56)$ & $228.71( \pm 46.22)$ & $234.23( \pm 46.14)$ \\
\hline $\mathrm{VCO}^{2}$ & $197.04( \pm 39.57)$ & $194.40( \pm 39.29)$ & $199.10( \pm 39.22)$ \\
\hline REE & $1628.52( \pm 326.88)$ & $1602.65( \pm 322.62)$ & $1647.16( \pm 324.44)$ \\
\hline Glycemia (mg/dL) & $92.77( \pm 15.81)$ & $93.83( \pm 15.11)$ & $92.34( \pm 16.19)$ \\
\hline Insulin $(\mu / \mu \mathrm{mL})$ & $8.23( \pm 4.4)$ & $6.80( \pm 4.50)$ & $9.08( \pm 4.25)$ \\
\hline Tot cholesterol (mg/dL) & $197.87( \pm 43.13)$ & $185.36( \pm 47.98)$ & $202.34( \pm 40.70)$ \\
\hline $\mathrm{HDL}(\mathrm{mg} / \mathrm{dL})$ & $54.5( \pm 15.86)$ & $58.46( \pm 16.82)$ & $53.10( \pm 15.40)$ \\
\hline $\mathrm{TG}(\mathrm{mg} / \mathrm{dL})$ & $109.31( \pm 50.71)$ & $95.40( \pm 49.41)$ & $114.22( \pm 50.61)$ \\
\hline LDL (mg/dL) & $122.21( \pm 30.01)$ & $111.17( \pm 33.38)$ & $126.05( \pm 28.00)$ \\
\hline GOT/AST (uL) & $22.16( \pm 9.05)$ & $21.91( \pm 12.63)$ & $22.24( \pm 7.64)$ \\
\hline GPT/ALT (uL) & $24.67( \pm 12.5)$ & $23.81( \pm 12.92)$ & $24.95( \pm 12.44)$ \\
\hline Basophils $(1000 / \mu \mathrm{L})$ & $0.02( \pm 0.03)$ & $0.03( \pm 0.03)^{\mathrm{a}}$ & $0.02( \pm 0.02)^{a}$ \\
\hline Basophils (\%) & $0.53( \pm 0.36)$ & $0.67( \pm 0.48)$ & $0.44( \pm 0.20)$ \\
\hline Eosinophils $(1000 / \mu \mathrm{L})$ & $0.23( \pm 0.37)$ & $0.36( \pm 0.64)$ & $0.17( \pm 0.10)$ \\
\hline Eosinophils (\%) & $3.07( \pm 2.01)$ & $3.81( \pm 2.87)$ & $2.74( \pm 1.40)$ \\
\hline НCT (\%) & $41.87( \pm 3.2)$ & $41.83( \pm 2.70)$ & $41.89( \pm 3.43)$ \\
\hline Hemoglobin (g/dL) & $14.11( \pm 1.32)$ & $14.05( \pm 1.11)$ & $14.14( \pm 1.41)$ \\
\hline 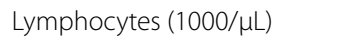 & $2.19( \pm 1.06)$ & $2.08( \pm 0.57)$ & $2.24( \pm 1.22)$ \\
\hline Lymphocytes (\%) & $32.75( \pm 7.3)$ & $33.08( \pm 7.69)$ & $32.62( \pm 7.22)$ \\
\hline
\end{tabular}


Table 1 (continued)

\begin{tabular}{|c|c|c|c|}
\hline & Total & TT genotype & A carriers \\
\hline $\mathrm{MCH}(\mathrm{pg})$ & $29.71( \pm 2.1)$ & $29.73( \pm 1.52)$ & $29.70( \pm 2.32)$ \\
\hline $\mathrm{MCHC}(\mathrm{g} / \mathrm{dL})$ & $33.66( \pm 1.43)$ & $33.74( \pm 1.42)$ & $33.64( \pm 1.45)$ \\
\hline MCV (fL) & $88.3( \pm 4.42)$ & $88.98( \pm 4.63)$ & $87.82( \pm 4.33)$ \\
\hline 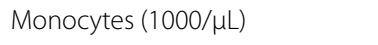 & $0.47( \pm 0.18)$ & $0.46( \pm 0.15)$ & $0.47( \pm 0.19)$ \\
\hline Monocytes (\%) & $7.29( \pm 2.03)$ & $7.21( \pm 1.46)$ & $7.32( \pm 2.24)$ \\
\hline Neutrophiles $(1000 / \mu \mathrm{L})$ & $3.64( \pm 1.15)$ & $3.59( \pm 1.04)$ & $3.67( \pm 1.25)$ \\
\hline Neutrophiles (\%) & $56.12( \pm 7.99)$ & $55.69( \pm 8.52)$ & $56.44( \pm 7.78)$ \\
\hline Plateles (1000/ML) & $205.83( \pm 36.84)$ & $210.17( \pm 39.32)$ & $202.94( \pm 35.96)$ \\
\hline RBC (million/ $\mu \mathrm{L})$ & $4.74( \pm 0.43)$ & $4.68( \pm 0.41)$ & $4.78( \pm 0.44)$ \\
\hline RDW-CV & $12.79( \pm 3.74)$ & $10.92( \pm 3.45)$ & $13.62( \pm 3.60)$ \\
\hline 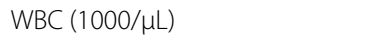 & $7.21( \pm 4)$ & $7.79( \pm 5.55)$ & $6.86( \pm 2.81)$ \\
\hline $\mathrm{ESR}(\mathrm{mm})$ & $31.03( \pm 68.58)$ & $36.00( \pm 86.37)$ & $29.14( \pm 62.24)$ \\
\hline Fibrinogen (mg/dL) & $290.29( \pm 168.28)$ & $351.40( \pm 85.57)$ & $264.10( \pm 193.31)$ \\
\hline Uric acid (mg/dL) & $8.84( \pm 9.14)$ & $10.64( \pm 11.23)$ & $8.14( \pm 8.26)$ \\
\hline $\mathrm{CRP}(\mathrm{mg} / \mathrm{dL})$ & $1.79( \pm 3.13)$ & $1.32( \pm 2.04)$ & $1.95( \pm 3.45)$ \\
\hline Kcal & $1721.86( \pm 731.69)$ & $1730.05( \pm 823.19)$ & $1711.23( \pm 636.34)$ \\
\hline Proteins (g) & $83.18( \pm 27.04)$ & $82.16( \pm 35.01)$ & $84.51( \pm 12.22)$ \\
\hline Proteins (\%) & $19.33( \pm 3.95)$ & $19.86( \pm 4.60)$ & $18.64( \pm 3.00)$ \\
\hline Carbohydrates (g) & $223.05( \pm 106.41)$ & $209.86( \pm 131.30)$ & $240.19( \pm 64.14)$ \\
\hline Carbohydrates (\%) & $46.88( \pm 7.63)$ & $46.19( \pm 8.43)$ & $47.78( \pm 6.78)$ \\
\hline Simple carbohydrates (g) & $75.83( \pm 33.01)$ & $75.06( \pm 43.41)$ & $76.82( \pm 12.23)$ \\
\hline Complex carbohydrates (g) & $128.72( \pm 55.39)$ & $125.68( \pm 64.34)$ & $132.68( \pm 44.16)$ \\
\hline Lipids (g) & $62.17( \pm 26.78)$ & $58.91( \pm 30.67)$ & $66.40( \pm 21.54)$ \\
\hline Lipids (\%) & $30.84( \pm 6.64)$ & $30.50( \pm 5.76)$ & $31.29( \pm 7.95)$ \\
\hline Total cholesterol (mg) & $218.90( \pm 90.23)$ & $218.67( \pm 106.36)$ & $219.20( \pm 69.40)$ \\
\hline Saturated fatty acids (g) & $17.02( \pm 10.07)$ & $15.84( \pm 11.65)$ & $18.55( \pm 7.89)$ \\
\hline Unsaturated fatty acids (g) & $8.80( \pm 4.07)$ & $7.21( \pm 3.72)^{\mathrm{a}}$ & $10.87( \pm 3.69)^{\mathrm{a}}$ \\
\hline Monounsaturated fatty acids (g) & $52.13( \pm 132.35)$ & $72.95( \pm 176.00)$ & $25.06( \pm 8.58)$ \\
\hline Polyunsaturated fatty acids (g) & $9.11( \pm 4.25)$ & $7.21( \pm 4.04)^{\mathrm{a}}$ & $11.42( \pm 3.39)^{\mathrm{a}}$ \\
\hline Fiber (g) & $22.63( \pm 9.92)$ & $20.50( \pm 5.09)$ & $25.39( \pm 13.82)$ \\
\hline
\end{tabular}

Descriptive table of the overall study population. Data were reported as mean and standard deviation. Statistical significance (a) among A carriers and TT genotype groups at baseline were given to results with $\mathrm{p}<0.05$ through t-test analysis

$B P$ blood pressure, $B M I$ body mass index, WHR waist hip ratio, $X$ c reactance, $R$ resistance, $P A$ phase angle, $B C M$ body cell mass, $H Y D R$ hydration, $N a / K$ sodium-potassium exchange, TBW total body water, ECW extracellular water, ICW intracellular water, BCMI body cell mass index, BFat body fat, TBFat: total body fat, $B L$ Lean body lean, TBLean total body lean, REE resting energy expenditure, $H D L$ high-density lipoprotein, $T G$ triglycerides, $L D L$ low-density lipoprotein, $G O T$ glutamic oxaloacetic transaminase, AST aspartate aminotransferase, GPT glutamate pyruvate transaminase, $A L T$ alanine transaminase, $H C T$ hematocrit, $M C H$ mean corpuscular hemoglobin, $M C H C$ mean corpuscular hemoglobin concentration, $M C V$ mean corpuscular volume, $R B C$ red blood cells, $R D W-C V$ red blood cell distribution width, WBC white blood cells, ESR erythrocyte sedimentation rate, CRP C-reactive protein

Table 2 Study population allele and genotype frequencies for FTO rs9939609 compared to Tuscan Italians from Southern Europe (TSI)

\begin{tabular}{llll}
\hline FTO rs9939609 & & & \\
\hline Allele frequency & A & T & \\
TSI & 0.46 & 0.54 & \\
Study population & 0.45 & 0.55 & \\
Genotype frequency & AA & AT & TT \\
TSI & 0.20 & 0.46 & 0.34 \\
Study population & 0.19 & 0.50 & 0.31 \\
\hline
\end{tabular}

Description of study population and genotype frequencies metabolic syndrome and type-2 diabetes $[2,4,5]$. Moreover, this type of dietetic model turns out to be fundamental both in preventing and treating the obesity $[6,42]$, which is becoming one of the most widespread medical condition in the world, since recent statistics demonstrated that, by 2030 , the $20 \%$ of the global adult population will be obese, and the $38 \%$ will be overweight [43]. Nevertheless, also genetics plays an important role in the development of the obesity [14]. So far, a wide number of genes are associated with the body composition, and one of the most studies is certainly FTO. Several variants 
Table 3 BMI distribution of study population according to FTO rs9939609 variant

\begin{tabular}{lll}
\hline BMI & TT & A carrier \\
$\mathbf{n = 3 7 ( 1 9 . 7 0 \% )}$ & $\mathbf{n = 1 5 1 ( 8 0 . 3 0 \% )}$ \\
\hline UW & $1(2.71 \%)$ & $3(1.99 \%)$ \\
NW & $5(13.51 \%)$ & $21(13.90 \%)$ \\
NWO & $3(8.11 \%)$ & $27(17.88 \%)$ \\
PreOb & $10(27.03 \%)$ & $49(32.46 \%)$ \\
OB I & $12(32.43 \%)$ & $23(15.23 \%)$ \\
OB II & $5(13.51 \%)$ & $10(6.62 \%)$ \\
OB III & $1(2.70 \%)$ & $18(11.92 \%)$ \\
\hline
\end{tabular}

Frequencies of carrier and non-carrier subjects according to the BMI. UW $(\mathrm{BMI}<18.50)$; $\mathrm{NW}(18.50 \leq \mathrm{BMI}<25$ or BMI $\geq 25$ plus TBFat $\%<30 \%$ females and $<25 \% \mathrm{M})$; NWO $(18.50 \leq \mathrm{BMI}<25$ plus Total TBFat $\% \geq 30 \%$ females and $>25 \%$ males); PreOb $(25<\mathrm{BMI}<30$ plus TBFat $\%>30 \%$ females and $>25 \%$ males); $\mathrm{Ob} \mathrm{I}(30 \leq \mathrm{BMI}<35) ; \mathrm{Ob}$ II $(35 \leq \mathrm{BMI}<40) ; \mathrm{Ob}$ III (BMI $\geq 40)$. BMI body mass index, UW underweight, NW normal-weight, NWO normal-weight obese, PreOb pre obese, $\mathrm{Ob}$ Obese

of this gene were associated with the BMI, and FTO rs9939609 is certainly one of the most known [44, 45]. In fact, its allele A is highly related with higher BMI $[20,46]$, fat and lean mass $[26,27]$. On the contrary, for the time being, several studies demonstrated that, during a dietetic treatment, FTO rs9939609 do not seem to influence the weight loss $[28,47]$. In view of above, we have conducted this study in order to analyze whether and how FTO rs9939609 variant influence both weight loss and body composition in Italian patients, within a Mediterranean dietetic treatment.

According to our results, TBW is highly influenced by FTO. In fact, analyzing the alteration of this value in each group (Table 4), it is possible to see that A carriers lost a higher quantity of body water compared to TT genotype $(\mathrm{MeD} / \mathrm{TT}$ genotype $=-0.83 \pm 1.63 ; \mathrm{CTR} / \mathrm{TT}$ genotype $=0.70 \pm 3.04 ; \mathrm{MeD} / \mathrm{A}$ carriers $=-1.88 \pm 4.35$; CTR/A carriers $=-1.75 \pm 3.28$ ) (Table 4$)$, whilst no difference due to $\mathrm{MeD}$ intervention was found. This result may be a confounding factor in the weight loss, since it influences the decreasing of both BMI and body weight during nutritional treatments, overestimating the effective fat mass loss. Analyzing the results of body composition evaluated via DXA, both dietetic treatment and interaction diet-gene influence the total body fat mass, whilst FTO alone did not demonstrate the same effect. Moreover, Gynoid BFat\% declining was highly related to the dietetic therapy, confirming that $\mathrm{MeD}$ treatment had an effect on body composition, confirming its capabilities, already demonstrated in several studies $[48,49]$, to reduce body fat, giving its important contribution against all the diseases related to the body fat mass. In our sample, the difference between the two nutritional treatments is highly considerable, since both $\mathrm{MeD}$ groups lost weight in a similar manner. It is also important to highlight that, in our sample, FTO did not influence the outcome of the nutritional treatment, thus confirming the results of previous studies $[28,50]$. These results might mean that, during a dietetic therapy, this SNP should not be taken into consideration, since it does not influence the outcome of both body composition and anthropometric measurements. However, the fact that also the interaction gene-diet had an effect on the TBFat suggests that, even though slightly, FTO might influence the outcome of the Mediterranean diet on this specific value, as previously proposed by another study [51]. Nonetheless, analyzing our results, it can be assumed that this statistical significance may be given by the incredible amount of TBFat gained by the A carriers/CTR group, thus suggesting an interesting role of this SNP in the development and preservation of body fat mass outside periods of nutritional therapies, as previously assumed by studies on murine models $[18,52]$. Considering these results, we suggest that understanding whether and how FTO, along with other genes or alone, influence the fat mass loss during nutritional treatments could help us to draft better clinical pictures of patients, and prevent difficulties of weight loss due to genetic factors. Moreover, both nutritional treatment and FTO alleles did not influence the lean mass, which, in contrast to the fat mass, remained almost steady within the studied period in all the analyzed groups. Finally, according to the statistical significance, in our sample, FTO rs9939609 did not influence body circumferences, weight, and consequently BMI. Nevertheless, even though in a non-significant manner, analyzing the data in Table 4, it can be seen how A carriers subjects lost less weight compared to TT genotype, following a trend already noted [53], and leaving some doubt about the effective activities of this SNP during nutritional treatments.

\section{Conclusions}

To conclude, Mediterranean diet confirmed to be useful in the prevention and treatment against obesity, since it demonstrated, in our sample, to reduce the body fat mass. On the contrary, data about FTO remain uncertain, and considering the importance of this SNP in the relation with BMI and body composition, further studies are needed to clarify definitely whether this SNP influences the outcome of the dietetic therapies. If FTO rs9939609 demonstrated to influence the decreasing of body tissues during nutritional treatments, its effect should be taken into consideration during both development of dietetic plans and monitoring of patients. 
Table 4 Anthropometric, body composition and REE analysis for FTO rs9939609 A carriers vs TT genotype in MeD and CTR groups

\begin{tabular}{|c|c|c|c|c|c|c|c|}
\hline & TT genotype & & A carriers & & P main & $\mathrm{P}$ main & $P$ main effect \\
\hline & $\begin{array}{l}\text { MeD } \\
(n=40)\end{array}$ & $\begin{array}{l}\text { CTR } \\
(n=17)\end{array}$ & $\begin{array}{l}\text { MeD } \\
(n=99)\end{array}$ & $\begin{array}{l}\text { CTR } \\
(n=32)\end{array}$ & rs9939609 & of diet & interaction \\
\hline Weight (kg) & & & & & 0.85 & 0.43 & 0.87 \\
\hline Baseline & $79.63(21.56)$ & $73.33(17.26)$ & $83.29(22.73)$ & $78.73(15.87)$ & & & \\
\hline Change & $-3.41(6.47)$ & $-1.27(3.89)$ & $-2.25(11.79)$ & $-0.62(1.26)$ & & & \\
\hline $\mathrm{BMI}$ & & & & & 0.92 & 0.33 & 0.81 \\
\hline Baseline & $29.03(7.39)$ & $25.74(3.64)$ & $30.4(7.35)$ & $28.50(6.03)$ & & & \\
\hline Change & $-1.28(2.34)$ & $-0.30(0.82)$ & $-0.85(4.27)$ & $-0.18(0.80)$ & & & \\
\hline Neck circumference (cm) & & & & & 0.50 & 0.78 & 0.37 \\
\hline Baseline & $40.54(3.39)$ & $36.75(3.28)$ & $41.03(4.19)$ & $36.88(3.76)$ & & & \\
\hline Change & $-0.60(0.42)$ & $-0.40(0.96)$ & $-1.09(2.13)$ & $-0.07(1.12)$ & & & \\
\hline Waist circumference $(\mathrm{cm})$ & & & & & 0.80 & 0.87 & 0.86 \\
\hline Baseline & $88.17(19.18)$ & $86.81(11.66)$ & $94.14(17.25)$ & $87.7(12.72)$ & & & \\
\hline Change & $-1.10(3.03)$ & $-0.78(1.82)$ & $-1.91(7.55)$ & $-1.10(2.34)$ & & & \\
\hline $\begin{array}{l}\text { Abdomen circumference } \\
(\mathrm{cm})\end{array}$ & & & & & 0.87 & 0.97 & 0.28 \\
\hline Baseline & $104.92(18)$ & $93.74(9.66)$ & $107.49(15.9)$ & $99.48(14.6)$ & & & \\
\hline Change & $-0.80(1.48)$ & $-1.04(3.46)$ & $-3.73(6.51)$ & $-1.13(2.89)$ & & & \\
\hline Hip circumference (cm) & & & & & 0.93 & 0.70 & 0.76 \\
\hline Baseline & $103.8(11.16)$ & $102.72(7.68)$ & $107.68(13.01)$ & $107.67(12.13)$ & & & \\
\hline Change & $-1.90(4.04)$ & $-1.38(3.55)$ & $-2.51(3.93)$ & $-1.44(3.29)$ & & & \\
\hline WHR & & & & & 0.80 & 0.89 & 0.89 \\
\hline Baseline & $0.84(0.12)$ & $0.84(0.08)$ & $0.87(0.12)$ & $0.82(0.08)$ & & & \\
\hline Change & $0.00(0.02)$ & $0.00(0.03)$ & $0.00(0.07)$ & $0.00(0.03)$ & & & \\
\hline $\mathrm{R}$ & & & & & 0.10 & 0.98 & 0.87 \\
\hline Baseline & 533.35 (88.18) & $545.31(80.2)$ & $484.66(107.09)$ & $507.77(78.38)$ & & & \\
\hline Change & $-3.00(22.26)$ & $0.24(33.1)$ & $20.11(59.77)$ & $25.91(42.27)$ & & & \\
\hline$X_{c}$ & & & & & 0.38 & 0.32 & 0.38 \\
\hline Baseline & $55.8(11.45)$ & $58.81(8.83)$ & $54.98(15.84)$ & $54.84(10.33)$ & & & \\
\hline Change & $0.00(4.76)$ & $-4.53(6.69)$ & $-2.2(10.33)$ & $-2.13(8.13)$ & & & \\
\hline PA & & & & & 0.73 & 0.45 & 0.58 \\
\hline Baseline & $6.23(1.06)$ & $6.24(1.22)$ & $6.62(1.54)$ & $6.22(1.07)$ & & & \\
\hline Change & $0.10(0.34)$ & $-0.40(0.79)$ & $-0.47(1.57)$ & $-0.53(0.94)$ & & & \\
\hline $\mathrm{BCM}(\mathrm{kg})$ & & & & & 0.17 & 0.91 & 0.94 \\
\hline Baseline & $27.29(6.39)$ & $28.95(8.13)$ & $31.99(9.68)$ & $29.66(6.28)$ & & & \\
\hline Change & $-0.33(0.98)$ & $-0.54(3.51)$ & $-2.62(7.63)$ & $-2.75(4.26)$ & & & \\
\hline $\mathrm{Na} / \mathrm{K}$ & & & & & 0.64 & 0.66 & 0.53 \\
\hline Baseline & $0.97(0.12)$ & $0.98(0.13)$ & $0.91(0.18)$ & $0.96(0.13)$ & & & \\
\hline Change & $0.03(0.1)$ & $0.06(0.1)$ & $0.06(0.17)$ & $-0.12(0.63)$ & & & \\
\hline TBW (L) & & & & & $0.02^{*}$ & 0.48 & 0.47 \\
\hline Baseline & $38.36(8.55)$ & 38.54 (8.94) & $41.76(10.99)$ & $39.81(6.57)$ & & & \\
\hline Change & $-0.83(1.63)$ & $0.70(3.04)$ & $-1.88(4.35)$ & $-1.75(3.28)$ & & & \\
\hline $\mathrm{ECW}(\mathrm{L})$ & & & & & 0.81 & 0.43 & 0.56 \\
\hline Baseline & $17.23(4.06)$ & $17.22(3.9)$ & $18.01(5.27)$ & $17.89(3.04)$ & & & \\
\hline Change & $-0.25(1.5)$ & $2.00(3.26)$ & $2.16(6.74)$ & $2.42(4.07)$ & & & \\
\hline ICW (L) & & & & & 0.65 & 0.92 & 0.81 \\
\hline Baseline & $21.12(5.16)$ & $17.22(3.9)$ & $23.75(6.97)$ & $20.59(4.05)$ & & & \\
\hline Change & $-0.25(0.74)$ & $-0.54(1.8)$ & $-1.89(4.85)$ & $-0.95(1.79)$ & & & \\
\hline
\end{tabular}


Table 4 (continued)

\begin{tabular}{|c|c|c|c|c|c|c|c|}
\hline & TT genotype & & A carriers & & & & \\
\hline & $\begin{array}{l}\text { MeD } \\
(n=40)\end{array}$ & $\begin{array}{l}\text { CTR } \\
(n=17)\end{array}$ & $\begin{array}{l}\text { MeD } \\
(n=99)\end{array}$ & $\begin{array}{l}\text { CTR } \\
(n=32)\end{array}$ & rs9939609 & of diet & interaction \\
\hline $\mathrm{BCMI}$ & & & & & 0.70 & 0.91 & 0.52 \\
\hline Baseline & $12.77(7.02)$ & $10.11(1.96)$ & 13.9 (8.08) & $10.56(1.94)$ & & & \\
\hline Change & $-0.10(0.34)$ & $-0.34(1)$ & $-2.40(6.81)$ & $-0.85(1.23)$ & & & \\
\hline Android Bfat (\%) & & & & & 0.60 & 0.09 & 0.93 \\
\hline Baseline & $44.92(12.45)$ & 37.34 (8.78) & $44.88(12.77)$ & $39.79(12.61)$ & & & \\
\hline Change & $-4.52(6.01)$ & $-1.00(2.16)$ & $-2.96(4.64)$ & $0.15(1.7)$ & & & \\
\hline Gynoid Bfat (\%) & & & & & 0.70 & $0.04^{*}$ & 0.32 \\
\hline Baseline & $43.51(10.63)$ & $36(7.85)$ & $41.8(77(11.76)$ & 39.07 (9.37) & & & \\
\hline Change & $-2.94(5.14)$ & $0.03(1.26)$ & $-1.67(3.51)$ & $-0.42(1.74)$ & & & \\
\hline TBFat (\%) & & & & & 0.79 & 0.08 & 0.94 \\
\hline Baseline & $37.92(9.45)$ & $33.16(6.05)$ & $38.08(10.34)$ & 36.14 (9.52) & & & \\
\hline Change & $-2.74(3.45)$ & $-0.19(1.14)$ & $-2.01(3.65)$ & $0.31(0.9)$ & & & \\
\hline Android Bfat (kg) & & & & & 0.89 & 0.27 & 0.91 \\
\hline Baseline & $3.02(1.96)$ & $2.32(1.08)$ & $3.3(2.17)$ & $2.78(1.39)$ & & & \\
\hline Change & $-0.47(0.53)$ & $-0.04(0.27)$ & $-0.45(1.18)$ & $-0.12(0.63)$ & & & \\
\hline Gynoid Bfat (kg) & & & & & 0.49 & 0.84 & 0.40 \\
\hline Baseline & $5.57(2.19)$ & $4.37(1.45)$ & $5.49(2.58)$ & $5.78(1.79)$ & & & \\
\hline Change & $-0.62(0.85)$ & $-0.46(1.25)$ & $-0.36(2.82)$ & $-0.94(2.25)$ & & & \\
\hline TBFat (Kg) & & & & & 0.06 & $0.00^{*}$ & $0.04^{*}$ \\
\hline Baseline & $31.34(14.5)$ & $21.32(8.66)$ & $32.85(15.56)$ & $23.24(12.11)$ & & & \\
\hline Change & $-3.59(4.78)$ & $1.93(5.54)$ & $-3.97(6.97)$ & $6.11(9.60)$ & & & \\
\hline Android BLean (kg) & & & & & 0.97 & 0.32 & 0.12 \\
\hline Baseline & $3.32(1.01)$ & $3.31(0.86)$ & $3.2(0.91)$ & $3.31(0.62)$ & & & \\
\hline Change & $-0.22(0.87)$ & $-0.08(0.15)$ & $0.11(0.6)$ & $-0.08(0.27)$ & & & \\
\hline Gynoid BLean (kg) & & & & & 0.49 & 0.92 & 0.91 \\
\hline Baseline & $6.77(1.86)$ & $7.24(2.16)$ & $6.79(1.9)$ & $7.08(1.26)$ & & & \\
\hline Change & $-0.20(1.54)$ & $-0.18(0.31)$ & $-0.56(5.66)$ & $0.01(0.33)$ & & & \\
\hline TBLean (kg) & & & & & 0.92 & 0.63 & 0.87 \\
\hline Baseline & $47.67(11.77)$ & $46.47(11.84)$ & $47.86(11.37)$ & $47.28(8.87)$ & & & \\
\hline Change & $-1.23(6.82)$ & $-0.53(1.05)$ & $-0.56(5.66)$ & $-0.61(2.08)$ & & & \\
\hline REE & & & & & 0.77 & 0.27 & 0.49 \\
\hline Baseline & 1639.92 (409.68) & $1664.96(217.89)$ & $1628.13(347.37)$ & $1583.46(313.51)$ & & & \\
\hline Change & $-48.13(327.01)$ & $-31.44(140.89)$ & $-44.01(220.32)$ & $-7.49(34.75)$ & & & \\
\hline
\end{tabular}

Relationship between FTO rs9939609 A carriers and TT genotype in body composition and metabolism, according to MeD and CTR groups. Statistical significance ${ }^{*}$ ) were given to results with $\mathrm{p}<0.05$ through GLM analysis. $B M I$ body mass index, WHR waist hip ratio, $R$ resistance, $X C$ reactance, $P A$ phase angle, $H Y D R$ hydration, NA/K sodium-potassium exchange, TBW total body water, ECW extracellular water, ICW intracellular water, BFat body fat, TBFat total body fat, BLean body lean, TBLean total body lean, $R E E$ resting energy expenditure

\section{Abbreviations}

ALT: alanine transaminase; AST: aspartate aminotransferase; BIA: bioelectrical impedence analysis; BCM: body cell mass; BCMI: body cell mass index; BFat: body fat mass; BLean: body lean mass; BMI: body mass index; BMC: bone min eral content; BMD: bone mineral density; BP: blood pressure; CDVs: cardiovascular diseases; CRP: C-reactive protein; CTR: control group; DXA: dual-energy $\mathrm{X}$-ray absorptiometry; ESR: erythrocyte sedimentation rate; ECW: extracellular water; FTO: fat mass and obesity-associated gene; GLM: generalized linear models; GPT: glutamate pyruvate transaminase; GOT: glutamic oxaloacetic transaminase; HWE: Hardy-Weinberg equilibrium; HCT: hematocrit; HDL: high-density lipoprotein; ICW: Intracellular Water; LDL: Iow-density lipoprotein; $\mathrm{MCH}$ : mean corpuscular hemoglobin; MCHC: mean corpuscular hemoglobin concentration; MCV: mean corpuscular volume; MeD: Mediterranean diet; NW: normal-weight; NWO: normal-weight obese; Ob: obese; OR: odds ratios; pD: P main effect of diet; pG: P main effect of FTO rs9939609; pGD: P main effect gene-diet interaction; PA: phase angle; PreOb: pre obese; $X_{c}$ : reactance; RBC: red blood cells; RDW-CV: red blood cell distribution width; $R$ : resistance; REE: resting expenditure rate; SNP: single nucleotide polymorphism; NA/K: sodium-potassium exchange; TSI: Toscans in Italy; TBBone: total body bone; TBFat: total body fat mass; TBLean: total body lean mass; TBW: total body water; TG: triglycerides; UW: underweight; WHR: waist hip ratio; WBC: white blood cells; WHO: World Health Organization. 


\section{Authors' contributions}

LDR conceived, designed the experiments, and drafted the manuscript; GC and SM draft the manuscript, performed the experiments, collected and analyzed the data; PS, LA and AM collected the data; ADL had primary responsibility for the final content. All authors take responsibility for all aspects of the reliability and freedom from bias of the data presented and their discussed interpretation. All the authors read and approved the final manuscript.

\begin{abstract}
Author details
${ }^{1}$ Section of Clinical Nutrition and Nutrigenomic, Department of Biomedicine and Prevention, University of Rome Tor Vergata, Via Montpellier 1, 00133 Rome, Italy. ${ }^{2}$ PhD School of Applied Medical-Surgical Sciences, University of Rome Tor Vergata, Via Montpellier 1, 00133 Rome, Italy. ${ }^{3}$ Department of Health Sciences, University of Magna Græcia, Viale Europa, Germaneto, 88100 Catanzaro, Italy. ${ }^{4}$ PhD School of History and Philosophical-social Sciences, University of Rome Tor Vergata, Via Orazio Raimondo 18, 00173 Rome, Italy.
\end{abstract}

\section{Acknowledgements}

The authors also thanks to all the subjects who participated volunteered in the clinical trial and the medical team of the Section of Clinical Nutrition and Nutrigenomic, Department of Biomedicine and Prevention, University of Rome Tor Vergata.

\section{Competing interests}

The authors declare that they have no competing interests.

\section{Availability of data and materials}

The datasets used and/or analyzed during the current study are available from the corresponding author on reasonable request.

\section{Consent for publication}

Not applicable.

Ethics approval and consent to participate

All participants enrolled in the study approved their participation studying and signing the informed consent, carried out in accordance with the Helsinki Declaration of 1975 as revised in 1983.

\section{Funding}

No funding was received.

\section{Publisher's Note}

Springer Nature remains neutral with regard to jurisdictional claims in published maps and institutional affiliations.

\section{Received: 6 Auqust 2018 Accepted: 6 November 2018}

\section{Published online: 12 November 2018}

\section{References}

1. Dinu M, Pagliai G, Casini A, Sofi F. Mediterranean diet and multiple health outcomes: an umbrella review of meta-analyses of observational studies and randomised trials. Eur J Clin Nutr. 2018;72(1):30-43. https://doi. org/10.1038/ejen.2017.58.

2. Widmer R, Flammer A, Lerman L, Lerman A. The Mediterranean diet, its components, and cardiovascular disease. Am J Med. 2015;128:229-38. https://doi.org/10.1016/j.amjmed.2014.10.014.

3. Esposito K, Maiorino Ml, Bellastella G, Chiodini P, Panagiotakos D, Giugliano D. A journey into a Mediterranean diet and type 2 diabetes: a systematic review with meta-analyses. BMJ Open. 2015;5(8):e008222. https://doi. org/10.1136/bmjopen-2015-008222.

4. Khemayanto $\mathrm{H}$, Shi B. Role of Mediterranean diet in prevention and management of type 2 diabetes. Chin Med J (Engl). 2014;127:3651-6.

5. Mayneris-Perxachs J, Sala-Vila A, Chisaguano M, Castellote Al, Estruch R, Covas Ml, et al. Effects of 1-year intervention with a Mediterranean diet on plasma fatty acid composition and metabolic syndrome in a population at high cardiovascular risk. PLoS ONE. 2014;9:e85202. https://doi. org/10.1371/journal.pone.0085202.
6. Esposito K, Kastorini CM, Panagiotakos DB, Giugliano D. Mediterranean diet and weight loss: meta-analysis of randomized controlled trials. Metab Syndr Relat Disord. 2011;9:1-12. https://doi.org/10.1089/ met.2010.0031.

7. Bendall CL, Mayr HL, Opie RS, Bes-Rastrollo M, Itsiopoulos C, Thomas CJ. Central obesity and the Mediterranean diet: a systematic review of intervention trials. Crit Rev Food Sci Nutr. 2017;17:1-15. https://doi. org/10.1080/10408398.2017.1351917.

8. World Health Organization. WHO Media Centre. Obesity and overweight: fact sheet. 2015. http://www.who.int/mediacentre/factsheets/fs311/en/.

9. WHO Expert Committee on Physical Status, World Health Organization. Physical status: the use of and interpretation of anthropometry, report of a WHO expert committee. 1995. http://www.who.int/iris/handle/10665 137003 .

10. De Lorenzo A, Soldati L, Sarlo F, Calvani MI, Di Lorenzo N, Di Renzo L. New obesity classification criteria as a tool for bariatric surgery indication. World J Gastroenterol. 2016;22:681-703. https://doi.org/10.3748/wjg.v22. i2.681.

11. Kuźbicka K, Rachoń D. Bad eating habits as the main cause of obesity among children. Pediatr Endocrinol Diabetes Metab. 2013;19:106-10.

12. World Health Organization. Commission on Ending Childhood Obesity. 2017. http://www.who.int/end-childhood-obesity/facts/en/.

13. Pi-Sunyer $X$. The medical risks of obesity. Postgrad Med. 2009;121:21-33. https://doi.org/10.3810/pgm.2009.11.2074.

14. Owen JB. Genetic aspects of body composition. Nutrition. 1999;15:609-13.

15. Fawcett KA, Barroso I. The genetics of obesity: FTO leads the way. Trends Genet. 2010;26:266-74. https://doi.org/10.1016/j.tig.2010.02.006.

16. Claussnitzer M, Dankel SN, Kim KH, Quon G, Meuleman W, Haugen C, et al. FTO obesity variant circuitry and adipocyte browning in humans. N Engl J Med. 2015;373(10):895-907. https://doi.org/10.1056/NEJMoa1502 214.

17. Hubáček JA, Pikhart H, Peasey A, Kubínová R, Bobák M. FTO variant, energy intake, physical activity and basal metabolic rate in Caucasians. The HAPIEE study. Physiol Res. 2011;60:175-83.

18. Church C, Moir L, McMurray F, Girard C, Banks GT, Teboul L, et al. Overexpression of Fto leads to increased food intake and results in obesity. Nat Genet. 2010;42:1086-92. https://doi.org/10.1038/ng.713.

19. Jia G, Yang CG, Yang S, Jian X, Yi C, Zhou Z, He C. Oxidative demethylation of 3-methylthymine and 3-methyluracil in single-stranded DNA and RNA by mouse and human FTO. FEBS Lett. 2008;582:3313-9. https://doi. org/10.1016/j.febslet.2008.08.019.

20. Frayling TM, Timpson NJ, Weedon MN, Zeggini E, Freathy RM, Lindgren $\mathrm{CM}$, et al. A common variant in the FTO gene is associated with body mass index and predisposes to childhood and adult obesity. Science. 2007;316:889-94

21. Peng S, Zhu Y, Xu F, Ren X, Li X, Lai M. FTO gene polymorphisms and obesity risk: a meta-analysis. BMC Med. 2011;9:71.

22. Vasan SK, Fall T, Job V, Gu HF, Ingelsson E, Brismar K, Karpe F, Thomas N. A common variant in the FTO locus is associated with waist-hip ratio in Indian adolescents. Pak J Med Dent. 2015;4:60-6. https://doi.org/10.111 1/j.2047-6310.2013.00118.x.

23. Sentinelli F, Incani M, Coccia F, Capoccia D, Cambuli VM, Romeo S, et al. Association of FTO polymorphisms with early age of obesity in obese Italian subjects. Exp Diabetes Res. 2012;2012:872176. https://doi. org/10.1155/2012/872176.

24. Fawwad A, Siddiqui IA, Zeeshan NF, Shahid SM, Basit A. Association of SNP rs9939609 in FTO gene with metabolic syndrome in type 2 diabetic subjects, rectruited from a tertiary care unit of Karachi, Pakistan. Pak J Med Sci. 2015;31:140-5. https://doi.org/10.12669/pjms.311.6524.

25. Yajnik CS, Janipalli CS, Bhaskar S, Kulkarni SR, Freathy RM, Prakash S, et al. FTO gene variants are strongly associated with type 2 diabetes in South Asian Indians. Diabetologia. 2009;52:247-52. https://doi.org/10.1007/ s00125-008-1186-6.

26. Kring SI, Holst C, Zimmermann E, Jess T, Berentzen T, Toubro S, et al. FTO gene associated fatness in relation to body fat distribution and metabolic traits throughout a broad range of fatness. PLoS ONE. 2008;13(3):e2958. https://doi.org/10.1371/journal.pone.0002958.

27. Sonestedt E, Gullberg B, Ericson U, Wirfält E, Hedblad B, Orho-Melander M. Association between fat intake, physical activity and mortality depending 
on genetic variation in FTO. Int J Obes (Lond). 2011;35:1041-9. https:// doi.org/10.1038/ijo.2010.263.

28. Livingstone KM, Celis-Morales C, Lara J, Ashor AW, Lovegrove JA, Martinez $J A$, et al. Associations between FTO genotype and total energy and macronutrient intake in adults: a systematic review and meta-analysis. Obes Rev. 2015;16:666-78. https://doi.org/10.1111/obr.12290.

29. Razquin C, Martinez JA, Martinez-Gonzalez MA, Bes-Rastrollo M Fernández-Crehuet J, Marti A. A 3-year intervention with a Mediterranean diet modified the association between the rs9939609 gene variant in FTO and body weight changes. Int J Obes (Lond). 2010;34:266-72. https://doi. org/10.1038/ijo.2009.233.

30. Ortega-Azorín C, Sorli JV, Asensio EM, Coltell O, Martínez-González MÁ, Salas-Salvadó J, Covas MI, Arós F, Lapetra J, Serra-Majem L, Gómez-Gracia E, Fiol M, Sáez-Tormo G, Pintó X, Muñoz MA, Ros E, Ordovás JM, Estruch R, Corella D. Associations of the FTO rs9939609 and the MC4R rs 17782313 polymorphisms with type 2 diabetes are modulated by diet, being higher when adherence to the Mediterranean diet pattern is low. Cardiovasc Diabetol. 2012;11:137. https://doi.org/10.1186/1475-2840-11-137.

31. Hosseini-Esfahani F, Koochakpoor G, Daneshpour MS, Sedaghati-Khayat B, Mirmiran P, Azizi F. Mediterranean dietary pattern adherence modify the association between FTO genetic variations and obesity phenotypes. Nutrients. 2017;9:E1064. https://doi.org/10.3390/nu9101064.

32. Lohman T, Roche A, Martorell R. Anthropometric standardization reference manual. Champaign: Human Kinetics Books; 1998. p. vi+ 177.

33. Uchegbu EC, Kopelman PG. Encyclopedia of Human Nutrition. 3rd ed. Hamilton: CDN; 2013. p. 374-83.

34. World Health Organization. Waist circumference and waist-hip ratio, report of a WHO expert consultation; 2016. http://whqlibdoc.who.int/ publications/2011/9789241501491_eng.pdf.

35. Shrey A, Coon C. Phenol-Chloroform Isoamyl Alcohol (PCI) DNA extraction. Modified from protocols by Barker et al, 1998. (http://hosted.usf.edu/ ecoimmunology/wp-content/uploads/2014/07/PCl-extraction.pdf).

36. Block G. Human dietary assessment: methods and issues. Prev Med. 1989;18:653-60.

37. Weir JB. New methods for calculating metabolic rate with special reference to protein metabolism. J Physiol. 1949;109:1-9.

38. De Lorenzo A, Di Renzo L, Morini P, de Miranda RC, Romano L, Colica C. New equations to estimate resting energy expenditure in obese adults from body composition. Acta Diabetol. 2018;55:59-66. https://doi. org/10.1007/s00592-017-1061-3.

39. Human energy requirements: report of a joint FAO/WHO/UNU expert consultation. Food Nutr Bull. 2005:26:166.

40. Græsli AR, Fahlman A, Evans AL, Bertelsen MF, Arnemo JM, Nielsen SS. Haematological and biochemical reference intervals for free-ranging brown bears (Ursus arctos) in Sweden. BMC Vet Res. 2014;10:183. https:// doi.org/10.1186/s12917-014-0183-x.

41. Romero-Corral A, Somers VK, Sierra-Johnson J, Thomas RJ, Bailey KR, Collazo-Clavell ML, et al. Accuracy of body mass index to diagnose obesity in the US adult population. Int J Obes. 2008;32(6):959-66. https://doi. org/10.1038/ijo.2008.11.
42. García-Fernández E, Rico-Cabanas L, Rosgaard N, Estruch R, Bach-Faig A. Mediterranean diet and cardiodiabesity: a review. Nutrients. 2014;6:3474500. https://doi.org/10.3390/nu6093474

43. Hruby A, Hu FB. The epidemiology of obesity: a big picture. Pharmacoeconomics. 2015;33:673-89. https://doi.org/10.1007/s40273-014-0243-x.

44. Wood AR, Tyrrell J, Beaumont R, Jones SE, Tuke MA, Ruth KS, GIANT consortium, Yaghootkar H, Freathy RM, Murray A, Frayling TM, Weedon MN. Variants in the FTO and CDKAL1 loci have recessive effects on risk of obesity and type 2 diabetes, respectively. Diabetologia. 2016;59(6):121421. https://doi.org/10.1007/s00125-016-3908-5.

45. Yang J, Loos RJ, Powell JE, Medland SE, Speliotes EK, Chasman DI, et al. FTO genotype is associated with phenotypic variability of body mass index. Nature. 2012;490(7419):267-72. https://doi.org/10.1038/natur e11401.

46. Qi Q, Kilpeläinen TO, Downer MK, Tanaka T, Smith CE, Sluijs I, et al. FTO genetic variants, dietary intake and body mass index: insights from 177,330 individuals. Hum Mol Genet. 2014;20(23):6961-72. https://doi. org/10.1093/hmg/ddu411.

47. Haupt A, Thamer C, Machann J, Kirchhoff K, Stefan N, Tschritter O, et al. Impact of variation in the FTO gene on whole body fat distribution, ectopic fat, and weight loss. Obesity. 2008;16:1969-72. https://doi. org/10.1038/oby.2008.283.

48. Sofi F, Dinu M, Pagliai G, Cesari F, Gori AM, Sereni A, et al. Low-calorie vegetarian versus Mediterranean diets for reducing body weight and improving cardiovascular risk profile: CARDIVEG study (cardiovascular prevention with vegetarian diet). Circulation. 2018;137:1103-13. https:// doi.org/10.1161/CIRCULATIONAHA.117.030088.

49. Boghossian NS, Yeung EH, Mumford SL, Zhang C, Gaskins AJ, WactawskiWende J, Schisterman EF, BioCycle Study Group. Adherence to the Mediterranean diet and body fat distribution in reproductive aged women. Eur J Clin Nutr. 2013:67:289-94. https://doi.org/10.1038/ejcn.2013.4.

50. Müller TD, Hinney A, Scherag A, Nguyen TT, Schreiner F, Schäfer H, Hebebrand J, Roth CL, Reinehr T. Fat mass and obesity associated' gene (FTO): no significant association of variant rs9939609 with weight loss in a lifestyle intervention and lipid metabolism markers in German obese children and adolescents. BMC Med Genet. 2008;9:85. https://doi. org/10.1186/1471-2350-9-85.

51. Zhang X, Qi Q, Zhang C, Smith SR, Hu FB, Sacks FM, Bray GA, Qi L. FTO genotype and 2-year change in body composition and fat distribution in response to weight-loss diets: the POUNDS LOST Trial. Diabetes. 2012;61:3005-11. https://doi.org/10.2337/db11-1799.

52. Fischer J, Koch L, Emmerling C, Vierkotten J, Peters T, Brüning JC, Rüther $\mathrm{U}$. Inactivation of the Fto gene protects from obesity. Nature. 2009:458(7240):894-8. https://doi.org/10.1038/nature07848.

53. Xiang L, Wu H, Pan A, Patel B, Xiang G, Qi L, Kaplan RC, Hu F, Wylie-Rosett J, Qi Q. FTO genotype and weight loss in diet and lifestyle interventions: a systematic review and meta-analysis. Am J Clin Nutr. 2016;103:1162-70. https://doi.org/10.3945/ajcn.115.123448.

Ready to submit your research? Choose BMC and benefit from:

- fast, convenient online submission

- thorough peer review by experienced researchers in your field

- rapid publication on acceptance

- support for research data, including large and complex data types

- gold Open Access which fosters wider collaboration and increased citations

- maximum visibility for your research: over $100 \mathrm{M}$ website views per year

At BMC, research is always in progress.

Learn more biomedcentral.com/submissions 